\title{
Seasonal changes of periphytic nutritive quality for Sicyopterus lagocephalus (Pallas, 1770) (gobiidae) in three streams of Reunion Island
}

\author{
S. Bielsa ${ }^{1 *}$, P. Francisco ${ }^{1}$, S. Mastrorillo ${ }^{2}$, J.P. Parent ${ }^{2}$ \\ 1 S.B.H., Avenue Salvador Allende, Les Ormes 2-D2, F-31320 Castanet, France. \\ 2 Laboratoire d'Ecologie des Hydrosystèmes, FRE 2630, Université Paul Sabatier, 118 route de Narbonne, F-31062 Toulouse Cedex, France.
}

\begin{abstract}
The biomass and the biochemical composition of periphyton were studied during one year in three streams of Réunion Island. The results revealed that nutritional conditions for fish development were most favourable during the dry season. The nutritive value of periphyton was highest in the Marsouins and Mât streams and remained the lowest in the Roches stream. Food availability was strongly affected by high flow, particularly during the exceptional hydrological events of February 1998 (cyclonic high flows). Study of seasonal variations of morphophysiological characteristics and biochemical composition (lipids, proteins) of the grazer gobiidae Sicyopterus lagocephalus showed that inspite of unfavourable nutritional conditions caused by hydrological disturbances, fish continue their reproduction which coincides with the summer high flow period. The significant depletion of lipid reserves which express a deterioration in animal condition is influenced by flooding period. At this time of gonad development involving an additional energy investment, fish were not able to recover a stable nutritional state after the complete achievement of the reproduction cycle. Except during this period, there is a weak participation of the reproductive physiological processes in the seasonal changes of somatic composition of this fish.
\end{abstract}

Keywords : Sicyopterus lagocephalus, periphyton, discharge, reproduction, biochemical composition.

\section{Introduction}

Much of the early work in tropical limnology focused on large lakes. Rivers and streams received less attention, and generally with emphasis on population structures and physical and chemical characteristics. The knowledge of these aquatic ecosystems is still insufficient to predict structural and functional responses to a possible environment deterioration (Crisman \& Streever 1996). Located in the tropical zone, Réunion Island has a dense hydrographic network. However, demographic growth rate, husbandry, industries and urbanisation involve an increase in the socio-economic needs and confronts Réunion Island with the problems of water shortage and deterioration of the hydrobiological resources quality. The first investigations relating

\footnotetext{
* corresponding author : E-mail : s.bielsa@free.fr
}

to freshwater hydrobiological characteristics already highlighted that some indigenous fish populations were threatened by both progressive destruction of their habitat and a too strong licit or illicit halieutic pressure (A.R.D.A. 1996). However, the lack of studies on the ecology and biology of fishes limits the possibilities of the definition of protection measures and relevant and effective management coupled with a rational exploitation of halieutics resources of these continental aquatic environments.

Juvenile gobiidae Sicyopterus lagocephalus (Pallas, 1770) - named «bichique» - are of social and economic interest. Due to a strong reduction of the juvenile captures observed during the last twenty years, this species was the first studied in terms of reproductive biology and habitat (Delacroix 1987, 1992). Results led the author to consider hypotheses whereby differences observed in spatial fish distribution could be linked to food availability constituted by periphyton. S. lagocephalus is considered as a grazer which primarily fed on 
periphytic algae (Bielsa 2000). Currently available data on benthic algae of Réunion Island are very scarce and only give a punctual view of the richness and floristic diversity (Bourrelly \& Couté 1986, Champeau 1982, O.R.E. 1999). Community structure analysis does not constitute a sufficient index to assess environment nutritional quality for the development of higher trophic levels. The biochemical analyses of biofilm combined with biomass data provide a closer estimate of food quantity and quality actually available for higher consumers. Moreover, the biochemical composition represents an integration of environmental fluctuations in addition to endogenous variations of the organisms (Reitan et al. 1994, Worm et al. 2000, Rathore \& Kumar 1993).

Gonadal development and fecundity depend on food quality and quantity. In the natural environment, food conditions are subjected to seasonal variations. Fish adaptation capacity to environmental fluctuations will be determining for both survival and reproductive success (Adams 1998). The aim of this work was to estimate nutritional conditions in Réunion streams for the fish Sicyopterus lagocephalus by studying spatio-temporal variations of the availability and quality (proteins, lipids) of periphytic food. The physiological fish responses in relation to environmental seasonal variations and to the reproduction cycle are discussed.

\section{Material and methods}

\section{Study area}

The study site is located on the windward coast, in North-East of Réunion Island. Six stations were selec- ted on three perennial streams which are amongst the most productive streams for the fish species Sicyopterus lagocephalus (Aboussouan 1969, Bertrand 1985), the Mât (stations I to III), the Roches (stations IV and V) and the Marsouins streams (station VI) (Fig. 1). Due to the very low fish densities in the upstream zone (Bielsa 2000), stations are located in the middle and downstream zones. The physico-chemical characteristics are given in Table 1.

\section{Sampling}

Samples were taken monthly from November 1997 to November 1998, during the period when exceptional cyclonic high flows occurred (February 1998).

Periphyton sampling was carried out by brushing about ten pebbles randomly taken along a transect. The sampling area was estimated by using tracing paper corresponding to the scraped area of each pebble. After weighing, paper weight allowed us to convert into $\mathrm{cm}^{2}$ and to give the total sampled surface. The collected bioderm was resuspended in stream water by rinsing the brush. An aliquot part was filtered (Whatman GF/C) for chlorophyl a analyses. Remaining biofilm was centrifuged and the pellets were immediately frozen in liquid nitrogen.

Simultaneously, about fifteen fish were captured by electric fishing (DEKA 3000, 600V / 5 A). Fish were killed, measured (standard length $+/-0.1 \mathrm{~cm}$ ) and weighed $(+/-0.01 \mathrm{G})$, then dissected. Gonads and liver were extirpated and weighed. Each fish was then crushed and immediately frozen in liquid nitrogen.

Biofilm samples and crushed frozen fish were dried in a vacuum dryer on Silicagel at ambient temperature

Table 1. Chemical characteristics of the study sites (mean \pm SD). (Alt. = Altitude, Temp. $=$ Temperature, $\mathrm{O}_{2}=$ dissolved oxygen, $\mathrm{C}=$ Conductivity) .

\begin{tabular}{|c|c|c|c|c|c|c|c|c|c|c|}
\hline Streams & Stations & $\begin{array}{l}\text { Alt. } \\
\text { (m) }\end{array}$ & $\begin{array}{l}\text { Temp. } \\
\left({ }^{\circ} \mathrm{C}\right)\end{array}$ & $\mathrm{pH}$ & $\begin{array}{c}\mathrm{O}_{2} \\
\left(\mathrm{mg} \cdot \mathrm{l}^{-1}\right)\end{array}$ & $\begin{array}{c}\mathrm{C} \\
\left(\mu \mathrm{S} . \mathrm{cm}^{-1}\right)\end{array}$ & $\begin{array}{l}\mathrm{N}-\mathrm{NO}_{2}{ }^{-} \\
\left(\mathrm{mg} \cdot \mathrm{l}^{-1}\right)\end{array}$ & $\begin{array}{l}\mathrm{N}-\mathrm{NO}_{3}{ }^{-} \\
\left(\mathrm{mg} \cdot \mathrm{l}^{-1}\right)\end{array}$ & $\begin{array}{l}\text { P-PO }{ }_{4}{ }^{3-} \\
\left(\mathrm{mg}^{-1} \mathrm{l}^{-1}\right)\end{array}$ & $\begin{array}{c}\mathrm{SiO}_{2} \\
\left(\mathrm{mg} \cdot \mathrm{l}^{-1}\right)\end{array}$ \\
\hline \multirow[t]{3}{*}{ Mât } & I & 210 & $19.7 \pm 2.7$ & $8.5 \pm 0.1$ & $9.5 \pm 1.0$ & $207.9 \pm 10.2$ & $0.01 \pm 0.001$ & $0.22 \pm 0.02$ & $0.05 \pm 0.007$ & $22.6 \pm 1.5$ \\
\hline & II & 90 & $23.0 \pm 2.9$ & $8.3 \pm 0.4$ & $9.0 \pm 0.8$ & $162.5 \pm 13.8$ & $0.01 \pm 0.003$ & $0.19 \pm 0.01$ & $0.05 \pm 0.006$ & $19.3 \pm 2.3$ \\
\hline & III & 13 & $23.5 \pm 3.0$ & $8.2 \pm 0.2$ & $9.1 \pm 0.6$ & $161.4 \pm 11.2$ & $0.01 \pm 0.003$ & $0.17 \pm 0.03$ & $0.05 \pm 0.01$ & $20.2 \pm 1.3$ \\
\hline \multirow[t]{2}{*}{ Roches } & IV & 17 & $20.4 \pm 1.8$ & $8.0 \pm 0.2$ & $9.8 \pm 0.8$ & $57.9 \pm 4.9$ & $0.01 \pm 0.002$ & $0.05 \pm 0.06$ & $0.02 \pm 0.003$ & $11.9 \pm 1.0$ \\
\hline & V & 5 & $22.0 \pm 2.7$ & $7.9 \pm 0.2$ & $10 \pm 0.9$ & $63.8 \pm 4.5$ & $0.005 \pm 0.002$ & $0.08 \pm 0.06$ & $0.02 \pm 0.003$ & $12.0 \pm 1.1$ \\
\hline Marsouins & VI & 32 & $19.4 \pm 2.3$ & $8.3 \pm 0.2$ & $10.1 \pm 0.8$ & $71.7 \pm 5.6$ & $0.01 \pm 0.002$ & $0.1 \pm 0.07$ & $0.04 \pm 0.002$ & $17.5 \pm 1.6$ \\
\hline
\end{tabular}




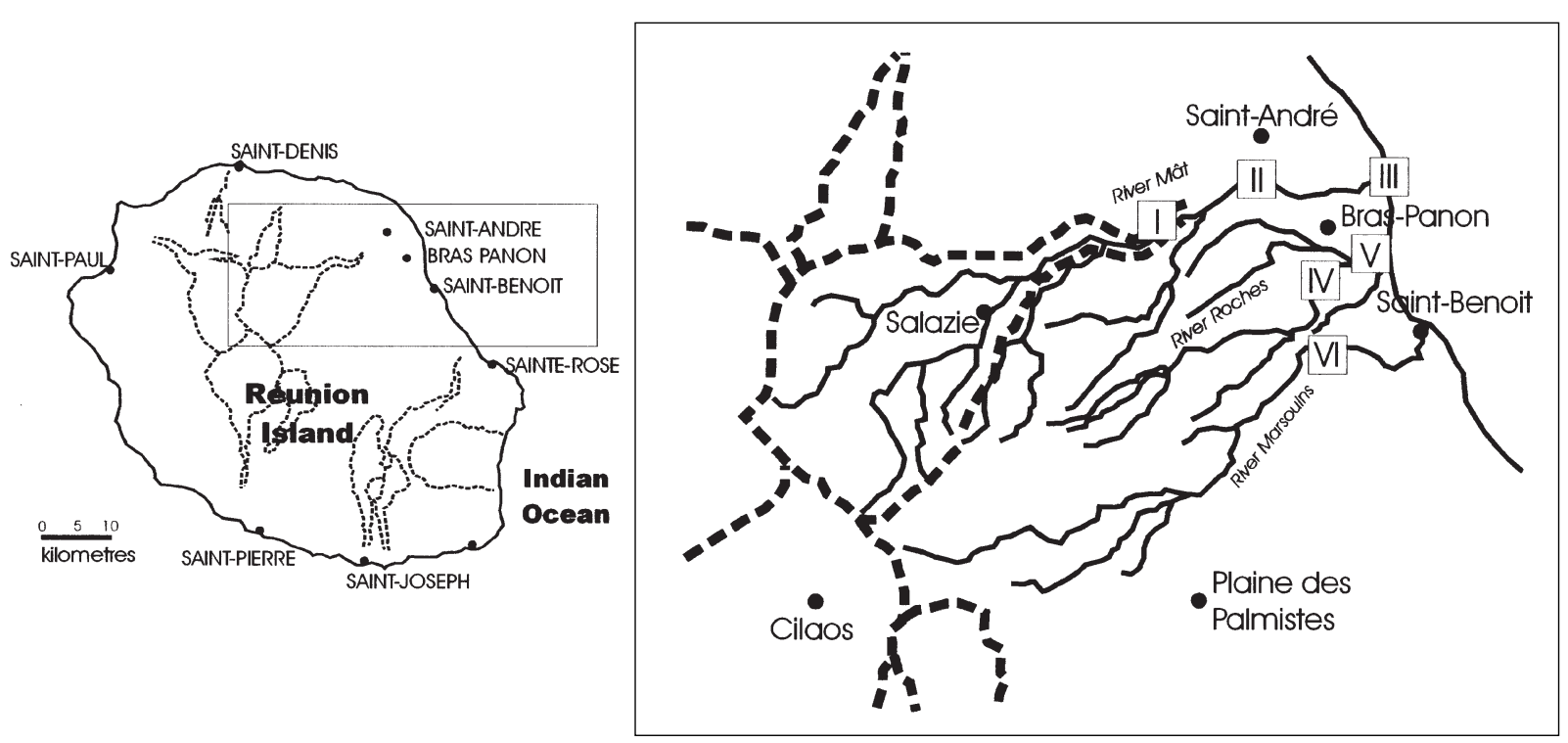

Fig. 1. Location of the study site and geographical distribution of sampling sites (I to III : Mât stream ; IV, V : Roches stream ; VI : Marsouins stream).

before transporting to the Toulouse Laboratory where they were reduced to powder (ZM 1000, Retsch) prior to biochemical analyses.

\section{Analytical techniques}

Total periphytic biomass was evaluated by quantification of the ash free dry mass (AFDM) and the algal fractin by chlorophyl a analysis. AFDM was determined by difference between dry weight and ashes obtained by incineration of dry matter in a muffle furnace $\left(550^{\circ} \mathrm{C}, 4 \mathrm{~h}\right)$ and expressed in $\mu \mathrm{g} . \mathrm{cm}^{-2}$. Chlorophyllian pigments were extracted according to ethanol ebullient method described by Marker et al. (1980). Chlorophyl a concentrations were calculated using Lorenzen (1967) equations and expressed per surface unit $\left(\mu \mathrm{g} . \mathrm{cm}^{-2}\right)$.

Total nitrogen was estimated by gas chromatography (Carlo Erba 2100 Elemental Analyzer). Protein quantity was calculated using a factor of 6.25. Total lipids were extracted according to Bligh \& Dyer (1959) and estimated gravimetrically. Protein and lipid contents of periphyton were expressed in $\%$ of the dry mass $(\%$ $\mathrm{DM}$ ) and also in an available quantity per surface unit ( $\mu$ g. $\mathrm{cm}^{-2}$ AFDM) by using biomass results.

\section{Morphophysiological parameters}

For each fish, gonadosomatic (\% GSI) and hepatosomatic (\% HSI) indexes were calculated from the following formulas :
GSI : [gonads weight (g) / (total weight - gonads weight) (g) ] X 100

HSI : [liver weight $(\mathrm{g})$ / (total weight - gonads weight) (g) ] X 100

\section{Statistical procedures}

Data variability along season or stations was evaluated by one-way analysis of variance (ANOVA) using Systat package (Wilkinson 1989). Where F value indicated significance $(\mathrm{P}<0.05)$, the differences between means in a given group were assessed with an a posteriori multiple comparison test (Tukey's Honesty Significant Difference test).

\section{Results}

\section{Periphyton}

Periphytic biomass (AFDM) varied between 0.1 and $1320 \mu \mathrm{g} . \mathrm{cm}^{-2}$ (Fig. 2). Whatever the stations, the highest values were generally observed during the dry season (June-July) and in early summer (October-November). The lowest values were recorded during the rainy season (February-March). On the Marsouins stream, the highest value was observed in June 1998 (station VI, $1320 \mu \mathrm{g} . \mathrm{cm}^{-2}$ ). The Roches stream was characterised by a weaker biomass peak $\left(530 \mu \mathrm{g} . \mathrm{cm}^{-2}\right)$ noticed in June-July (stations V and IV). On the Mât stream, biomass peaked in June (II) and in October- 

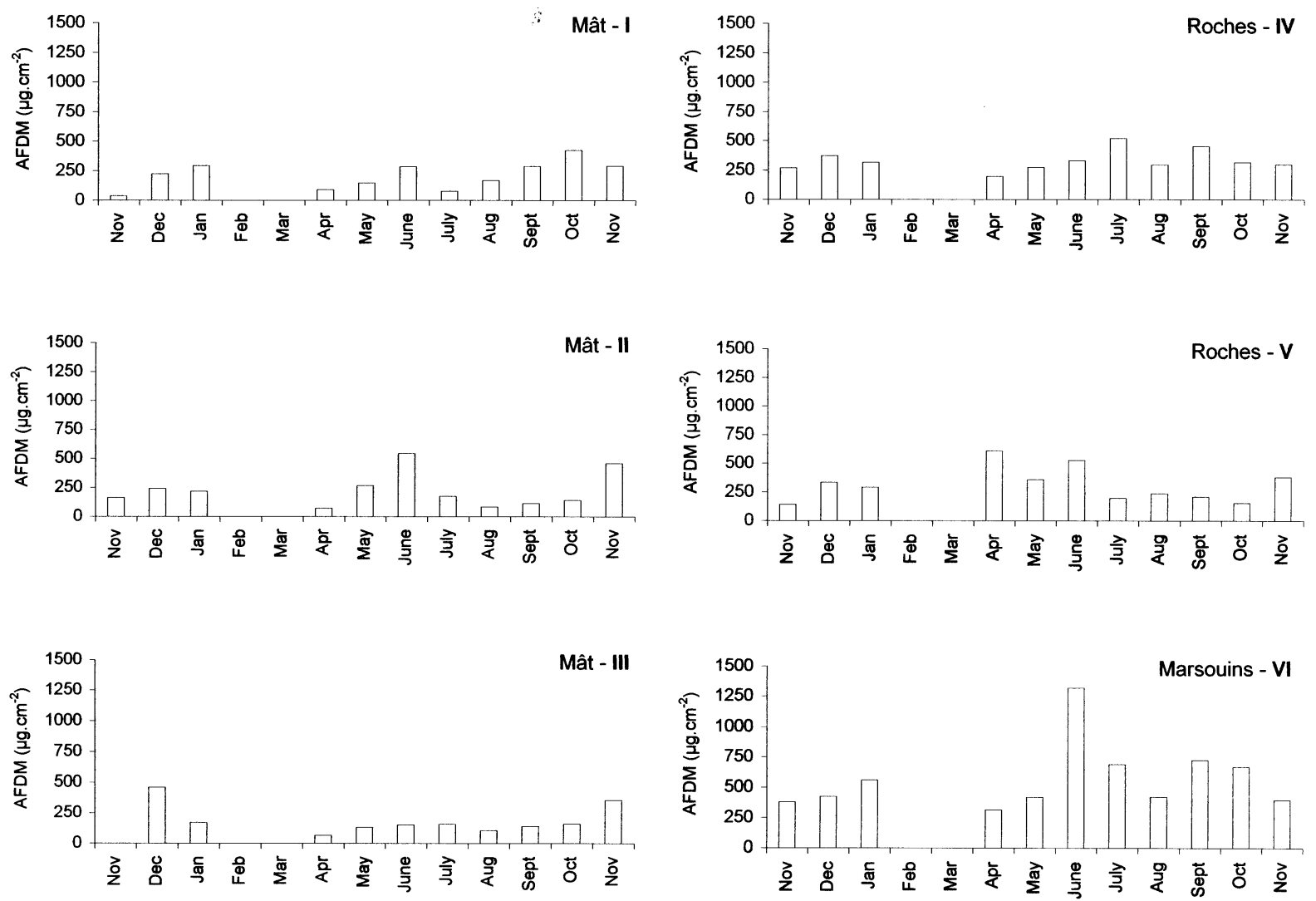

Fig. 2. Seasonal changes in periphytic ash free dry mass (AFDM, $\mu$ g. $\mathrm{cm}^{-2}$ ) at sampling sites I - VI.

November (I and III) but values remained overall lower than those recorded on the other streams. The lowest values were generally recorded near the stream mouth (station III).

Chlorophyl a concentrations fluctuated between 0.2 and $11.1 \mu \mathrm{g} . \mathrm{cm}^{-2}$ (Fig. 3). Seasonal variations were similar to those recorded for ash free dry mass. The highest values were observed in the dry period, the lowest during the high flow season. The most significant algal biomass was recorded on the Marsouins stream (VI), weakest in the biofilm taken close to the Mât mouth stream (III).

Average protein contents of the periphyton varied between 12 and $21 \%$ DM (fig. 4). Monthly variations indicated that proteins were highest between August and October and lowest in May-June. Biofilm was richer in proteins on the Marsouins stream (21\%, VI) while the lowest average concentrations were recorded on the Roches stream (IV, $12 \%$; V, $15 \%$ ). An inter- mediate value was noticed on the Mât stream stations (17-19\%).

Mean lipids levels of the periphyton varied between 1.8 and $2.6 \%$ (\% DM) (Fig. 5). Lipid contents were highest from April to August, during the dry season, and lowest during the rainy season (February-March). The minima were observed on stations IV and V $(1.9 \%)$ of the Roches stream and the maximum on the Marsouins stream (VI, $2.6 \%$ ). Values recorded on the Mât never exceeded $2.2 \%$ (I, $2 \%$; II, $2.2 \%$; III, $2 \%$ ).

Protein and lipid availability, expressed in $\mu \mathrm{g} . \mathrm{cm}^{-2}$ AFDM, varied according to total periphytic biomass. Mean annual protein levels ranged between 65 and 205 $\mu \mathrm{g} . \mathrm{cm}^{-2}$ (Fig. 4). The highest values were recorded during the dry season (June-July and October-November) and the lowest during the high flow period (FebruaryMarch). The highest concentrations were noticed on station VI and the lowest downstream from the Mât stream (III). They oscillated around $100 \mu \mathrm{g} . \mathrm{cm}^{-2}$ on 

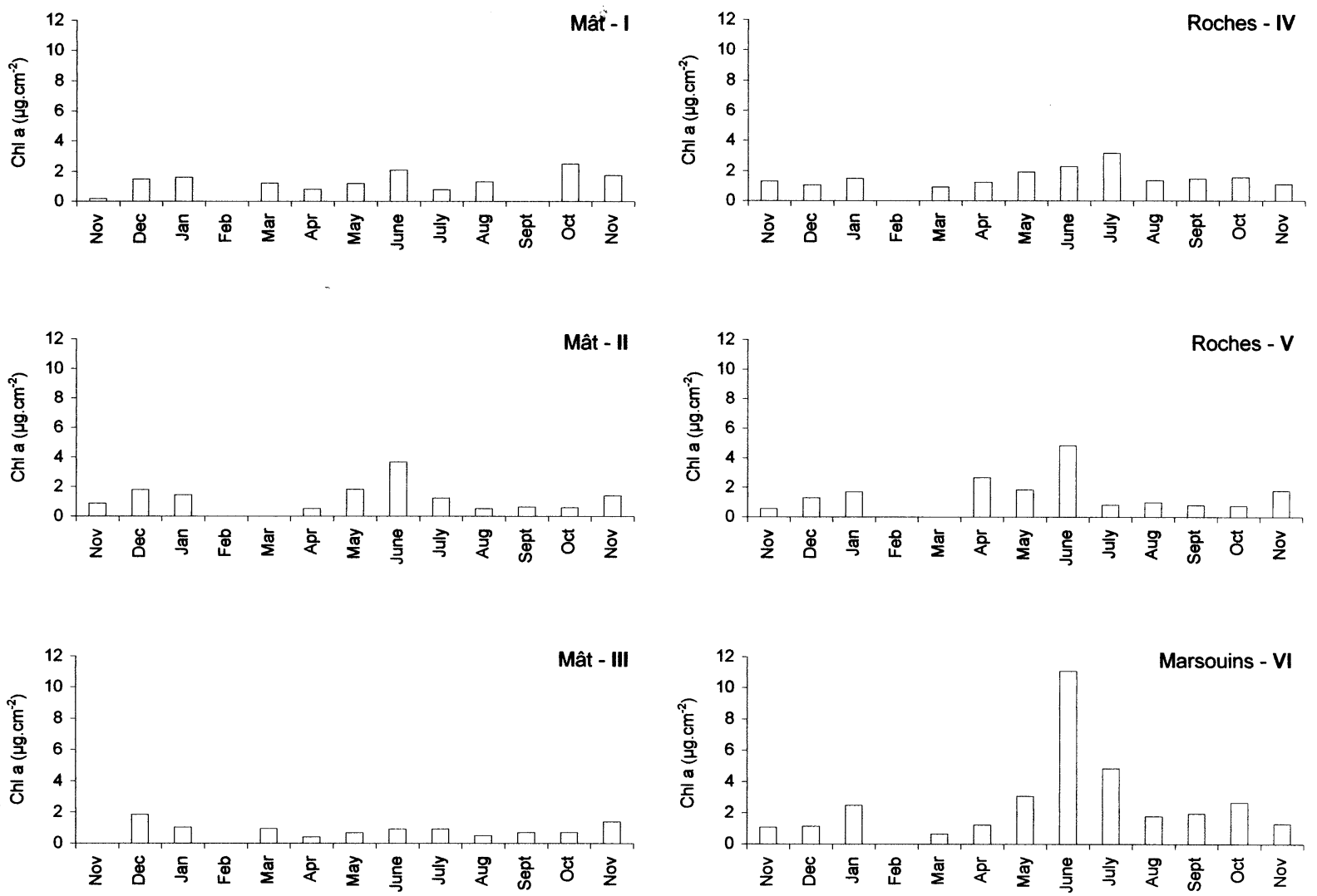

Fig. 3. Seasonal changes in periphytic chlorophyll a $\left(\mu \mathrm{g} . \mathrm{cm}^{-2}\right)$ at sampling sites I - VI.

other studied sites. Mean annual lipid contents of the periphyton varied between 7.9 and $34.3 \mu \mathrm{g} . \mathrm{cm}^{-2}$ (AFDM) from June to November and between 2.8 and $27.2 \mu \mathrm{g} . \mathrm{cm}^{-2}$ from March to May (Fig. 5). Annual average concentrations were the highest on station VI $\left(26.1 \mu \mathrm{g} . \mathrm{cm}^{-2}\right)$. They ranged between 11 and $14 \mu \mathrm{g} . \mathrm{cm}^{-2}$ on sites II (Mât) and IV, V (Roches) respectively and never exceeded $8 \mu \mathrm{g} . \mathrm{cm}^{-2}$ on stations I and III (Mât).

\section{Sicyopterus lagocephalus}

Physiological parameters were mesured on adult fish (mean standard length: $8 \pm 0.5 \mathrm{~cm}$; mean weight: $10 \pm 2 \mathrm{~g})$.

Gonadosomatic index (\% GSI) varied significantly $(\mathrm{P}<0.001)$ between males and females, throughout the year (Tables 2, 3). Females presented the highest mean values ranging between 0.7 and $11.2 \%$, whereas males oscillated between 0.1 and $0.5 \%$. Seasonal fluctuations were similar for both sexes but the magnitude va- riations of males were less marked. During reproductive cycle, the gonadosomatic index increased significantly from November and remained high until May. From May GSI decreased until the lowest values were recorded between July and September.

Hepatosomatic index (\% HSI) fluctuated between 1 and $10 \%$ (Tables 2,3). The highest values were observed between October and December $(>5 \%)$ and the lowest from March to May $(<4 \%)$. HSI increased from June to December. The highest values were observed in females and were significantly higher than in males. In contrast, percentages were weaker in summer and higher in males. Hepatosomatic index was higher on station VI (Marsouins) whereas values were lower on downstream stations (III, V).

Total somatic lipid level of $S$. lagocephalus varied between 2 and $12.2 \%$ of dry mass (Fig. 6). During the dry season (May - November), percentages increased significantly $(\mathrm{P}<0.001)$. The lowest values were re- 

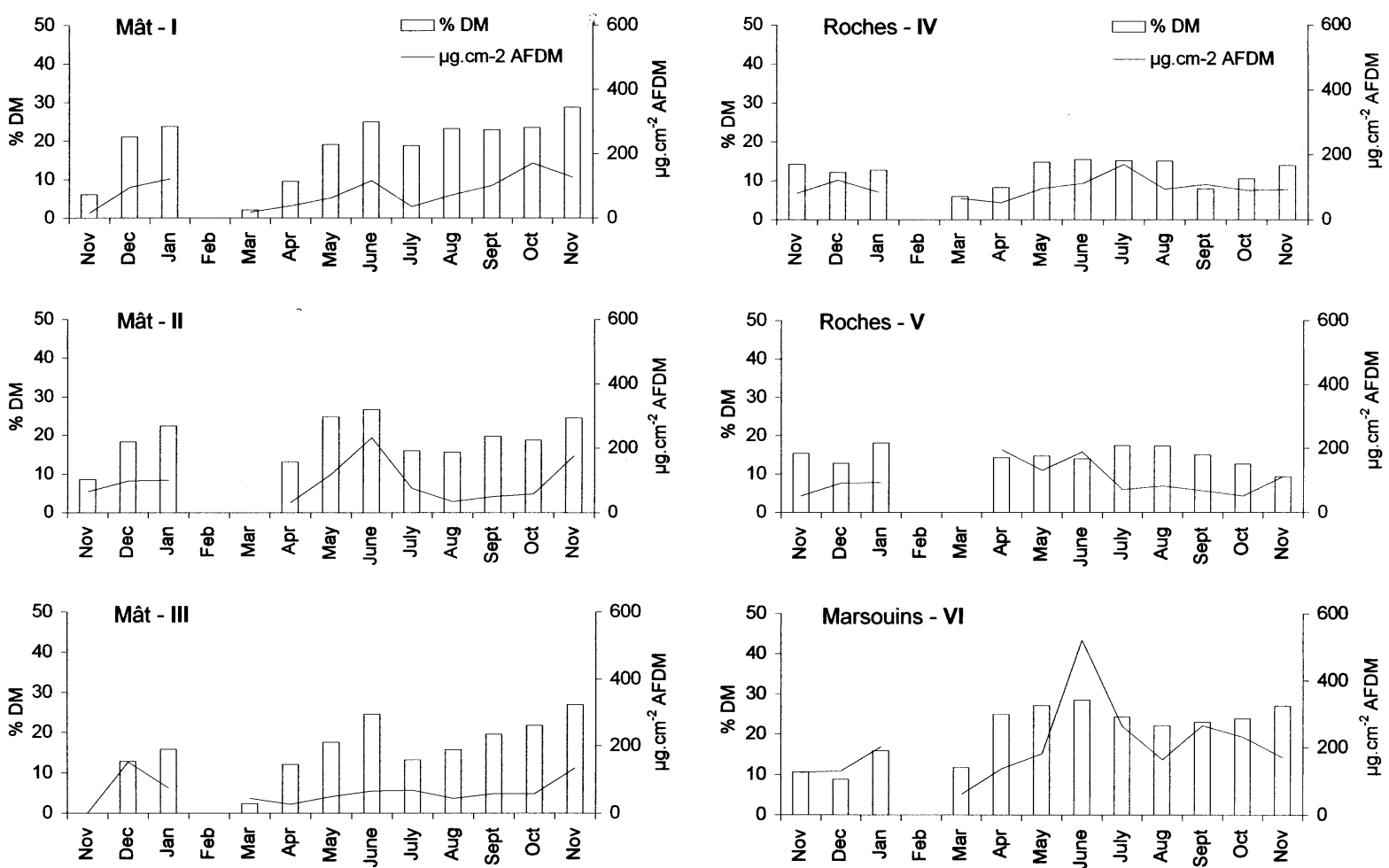

Fig. 4. Seasonal changes in total proteins of periphyton (\% dry weight and $\mu \mathrm{g} . \mathrm{cm}^{-2}$ ash free dry mass) at sampling sites I - VI.

Table 2. Seasonal changes in gonadosomatic (\% GSI) and hepatosomatic (\% HSI) indexes of S. lagocephalus from Mât stream (mean \pm SD).

\begin{tabular}{|c|c|c|c|c|c|c|c|c|c|c|c|c|}
\hline \multirow{3}{*}{$\begin{array}{l}\text { Stations } \\
\text { Parameters }\end{array}$} & \multicolumn{4}{|c|}{ I } & \multicolumn{4}{|c|}{ II } & \multicolumn{4}{|c|}{ III } \\
\hline & \multicolumn{2}{|c|}{ GSI } & \multicolumn{2}{|c|}{ HSI } & \multicolumn{2}{|c|}{ GSI } & \multicolumn{2}{|c|}{ HSI } & \multicolumn{2}{|c|}{ GSI } & \multicolumn{2}{|c|}{ HSI } \\
\hline & male & female & male & female & male & female & male & female & male & female & male & female \\
\hline Nov. & $0.21 \pm 0.07$ & $1.13 \pm 0.75$ & $3.88 \pm 1.81$ & $5.05 \pm 2.42$ & $0.30 \pm 0.05$ & $5.77 \pm 2.98$ & $6.06 \pm 1.38$ & $5.83 \pm 1.57$ & & & & \\
\hline Dec. & $0.21 \pm 0.05$ & $1.80 \pm 0.69$ & $5.86 \pm 2.06$ & $7.30 \pm 1.81$ & $0.27 \pm 0.13$ & $11.2 \pm 8.13$ & $5.61 \pm 1.78$ & $5.45 \pm 0.87$ & $0.39 \pm 0.06$ & $6.00 \pm 3.75$ & $4.34 \pm 1.35$ & $5.97 \pm 1.13$ \\
\hline \multirow{2}{*}{\multicolumn{13}{|c|}{$\begin{array}{l}0.3510 .00 \\
\end{array}$}} \\
\hline & & & & & & & & & & & & \\
\hline Mar & $0.28 \pm 0.08$ & $2.75 \pm 2.33$ & $1.25 \pm 0.11$ & $2.54 \pm 0.82$ & & & & & $0.39 \pm 0.39$ & $2.47 \pm 2.24$ & $1.66 \pm 0.54$ & $2.48 \pm 1.75$ \\
\hline Apr. & $0.28 \pm 0.06$ & $3.03 \pm 4.03$ & $1.99 \pm 0.57$ & $2.25 \pm 0.65$ & $0.27 \pm 0.04$ & $1.03 \pm 0.27$ & $1.29 \pm 0.03$ & $1.77 \pm 0.75$ & $0.34 \pm 0.12$ & $1.56 \pm 0.93$ & $1.80 \pm 0.96$ & $1.39 \pm 0.63$ \\
\hline May & $0.18 \pm 0.06$ & $1.27 \pm 0.28$ & $2.31 \pm 0.81$ & $2.27 \pm 0.85$ & & & & & $0.25 \pm 0.07$ & $2.69 \pm 3.54$ & $1.38 \pm 0.40$ & $1.46 \pm 0.45$ \\
\hline June & $0.23 \pm 0.06$ & $1.11 \pm 0.47$ & $2.33 \pm 1.06$ & $3.09 \pm 1.33$ & & & & & $0.27 \pm 0.05$ & $7.33 \pm 5.71$ & $2.31 \pm 0.64$ & $3.24 \pm 0.54$ \\
\hline Jul. & $0.23 \pm 0.04$ & $0.83 \pm 0.10$ & $1.67 \pm 0.63$ & $1.88 \pm 0.43$ & $0.31 \pm 0.03$ & $4.63 \pm 3.27$ & $3.95 \pm 1.32$ & $3.89 \pm 0.77$ & $0.36 \pm 0.10$ & $3.02 \pm 0.98$ & $1.83 \pm 1.00$ & $2.06 \pm 0.41$ \\
\hline Aug. & $0.17 \pm 0.05$ & $0.99 \pm 0.11$ & $3.19 \pm 1.21$ & $5.08 \pm 1.08$ & & & & & $0.26 \pm 0.08$ & $3.33 \pm 2.86$ & $2.47 \pm 0.57$ & $2.32 \pm 0.61$ \\
\hline Sept. & & & & & & & & & $0.29 \pm 0.08$ & $4.33 \pm 4.96$ & $1.89 \pm 1.05$ & $2.01 \pm 1.09$ \\
\hline Oct. & $0.21 \pm 0.07$ & $4.32 \pm 4.13$ & $6.76 \pm 1.13$ & $7.04 \pm 2.53$ & & $8.10 \pm 5.05$ & & $4.92 \pm 0.85$ & $0.42 \pm 0.13$ & $8.62 \pm 6.64$ & $3.39 \pm 0.65$ & $4.62 \pm 0.87$ \\
\hline Nov. & $0.30 \pm 0.07$ & $5.10 \pm 2.94$ & $6.76 \pm 1.48$ & $7.70 \pm 1.63$ & & & & & $0.53 \pm 0.11$ & $5.79 \pm 5.15$ & $3.91 \pm 0.57$ & $4.01 \pm 0.92$ \\
\hline
\end{tabular}



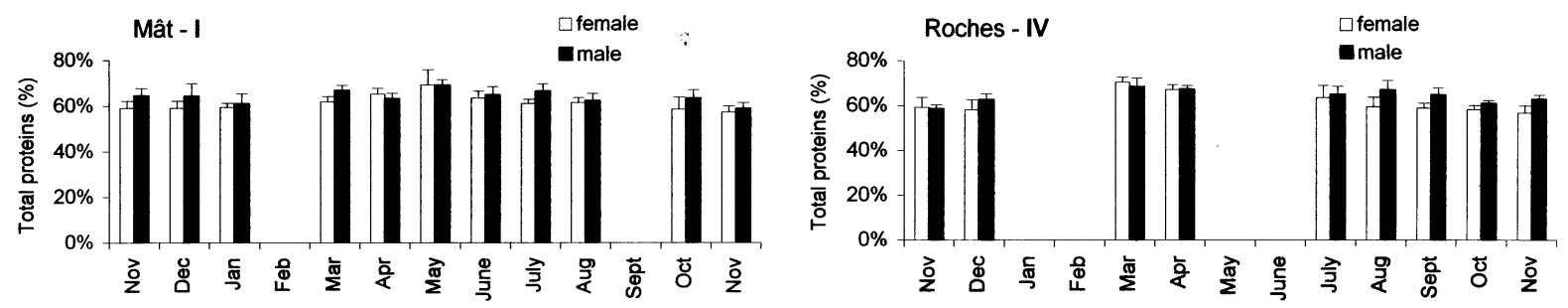

Mât - II
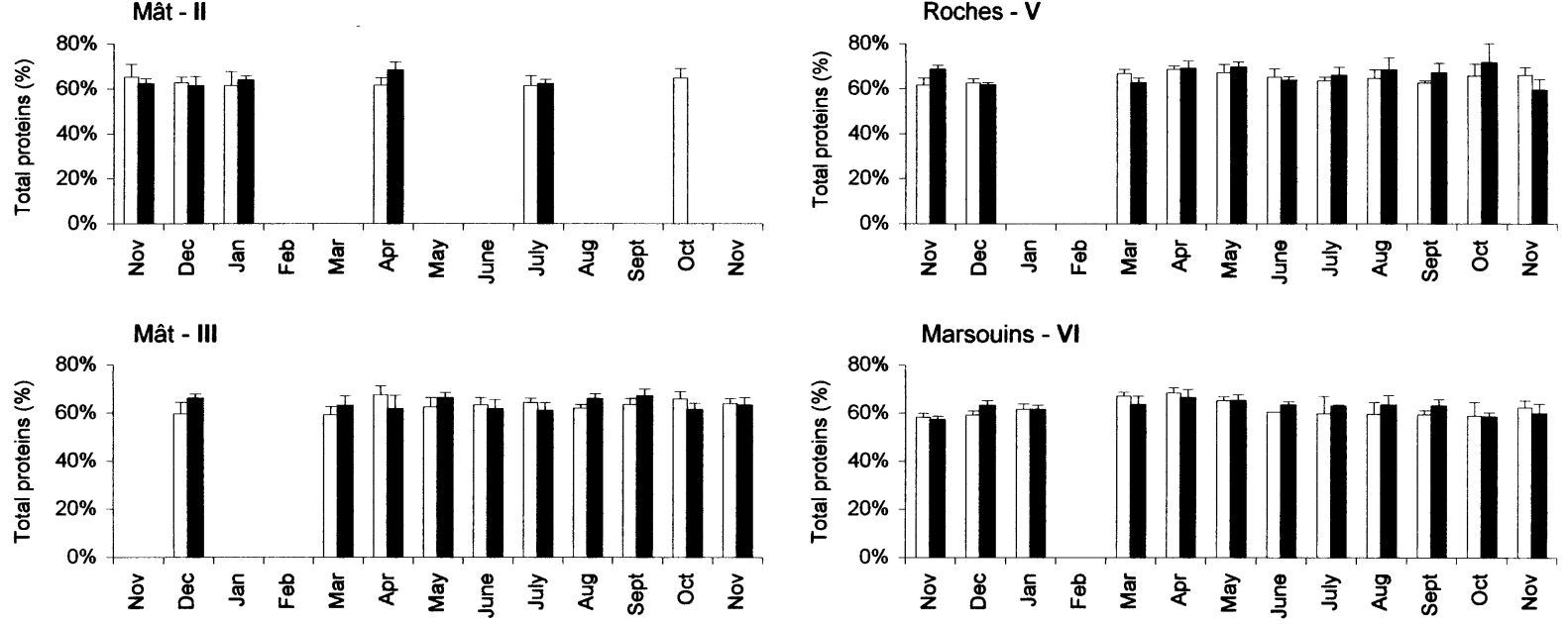

Fig. 5. Seasonal changes in total lipids of periphyton (\% dry weight and $\mu \mathrm{g} . \mathrm{cm}^{-2}$ ash free dry mass) at sampling sites I - VI.

Table 3. Seasonal changes in gonadosomatic (\% GSI) and hepatosomatic (\% HSI) indexes of S. lagocephalus from Roches (IV, V) and Marsouins (VI) streams.

\begin{tabular}{|c|c|c|c|c|c|c|c|c|c|c|c|c|}
\hline \multirow{3}{*}{$\begin{array}{l}\text { Stations } \\
\text { Parameters }\end{array}$} & \multicolumn{4}{|c|}{ IV } & \multicolumn{4}{|c|}{$\mathbf{V}$} & \multicolumn{4}{|c|}{ VI } \\
\hline & \multicolumn{2}{|c|}{ GSI } & \multicolumn{2}{|c|}{ HSI } & \multicolumn{2}{|c|}{ GSI } & \multicolumn{2}{|c|}{ HSI } & \multicolumn{2}{|c|}{ GSI } & \multicolumn{2}{|c|}{ HSI } \\
\hline & male & female & male & female & male & female & male & female & male & female & male & female \\
\hline Nov. & $0.21 \pm 0.10$ & $0.88 \pm 0.18$ & $6.41 \pm 0.08$ & $5.92 \pm 1.27$ & $0.17 \pm 0.06$ & $0.73 \pm 0.15$ & $2.72 \pm 1.53$ & $3.19 \pm 0.94$ & $0.28 \pm 0.03$ & $8.74 \pm 4.33$ & $7.03 \pm 1.40$ & $9.45 \pm 1.17$ \\
\hline Dec. & $0.25 \pm 0.08$ & $2.83 \pm 2.47$ & $5.26 \pm 0.97$ & $6.53 \pm 1.61$ & $0.17 \pm 0.07$ & $0.81 \pm 0.21$ & $2.54 \pm 0.83$ & $3.83 \pm 0.94$ & $0.38 \pm 0.11$ & $10.5 \pm 4.97$ & $5.60 \pm 1.41$ & $8.14 \pm 0.51$ \\
\hline Jan. & & & & & & & & & $0.33 \pm 0.10$ & $9.14 \pm 6.45$ & $5.97 \pm 0.75$ & $6.42 \pm 0.73$ \\
\hline $\begin{array}{l}\text { Feb. } \\
\text { Mar }\end{array}$ & & & & & & & & & & & & \\
\hline Mar & $0.41 \pm 0.10$ & $8.17 \pm 5.24$ & $1.42 \pm 0.26$ & $1.93 \pm 0.73$ & $0.39 \pm 0.08$ & $7.35 \pm 5.74$ & $2.08 \pm 1.13$ & $2.02 \pm 0.48$ & $0.42 \pm 0.09$ & $6.59 \pm 3.85$ & $2.70 \pm 1.05$ & $2.85 \pm 0.42$ \\
\hline Apr. & $0.41 \pm 0.03$ & $8.50 \pm 5.18$ & $3.25 \pm 0.59$ & $2.28 \pm 0.59$ & $0.34 \pm 0.06$ & $6.71 \pm 4.87$ & $2.39 \pm 0.85$ & $1.72 \pm 0.26$ & $0.42 \pm 0.06$ & $11.1 \pm 9.00$ & $2.63 \pm 1.15$ & $2.92 \pm 0.70$ \\
\hline May & & & & & $0.27 \pm 0.07$ & $2.47 \pm 1.48$ & $2 ., 13 \pm 0.93$ & $1.89 \pm 0.80$ & $0.37 \pm 0.05$ & $6.30 \pm 5.36$ & $2.92 \pm 1.06$ & $3.48 \pm 0.50$ \\
\hline June & & & & & $0.33 \pm 0.10$ & $2.95 \pm 2.59$ & $2.80 \pm 1.00$ & $2.04 \pm 0.62$ & $0.33 \pm 0.09$ & $3.09 \pm 2.14$ & $4.60 \pm 0.55$ & $4.91 \pm 1.10$ \\
\hline Jul. & $0.20 \pm 0.07$ & $1.03 \pm 0.18$ & $4.16 \pm 0.81$ & $5.70 \pm 0.93$ & $0.32 \pm 0.07$ & $2.20 \pm 3.19$ & $3.07 \pm 1.23$ & $2.78 \pm 0.63$ & $0.24 \pm 0.03$ & $1.31 \pm 0.30$ & $3.37 \pm 0.94$ & $4.93 \pm 1.13$ \\
\hline Aug. & $0.23 \pm 0.03$ & $0.89 \pm 0.06$ & $5.09 \pm 0.45$ & $6.76 \pm 1.26$ & $0.23 \pm 0.11$ & $0.82 \pm 0.07$ & $2.88 \pm 0.66$ & $4.09 \pm 0.92$ & $0.23 \pm 0.04$ & $1.17 \pm 0.23$ & $5.35 \pm 1.17$ & $6.50 \pm 1.14$ \\
\hline Sept. & $0.20 \pm 0.04$ & $0.94 \pm 0.14$ & $5.11 \pm 1.08$ & $7.20 \pm 0.83$ & $0.31 \pm 0.06$ & $0.84 \pm 0.40$ & $3.22 \pm 1.13$ & $3.95 \pm 0.92$ & $0.23 \pm 0.03$ & $1.21 \pm 0.16$ & $5.93 \pm 0.55$ & $7.64 \pm 1.10$ \\
\hline Oct. & $0.27 \pm 0.17$ & $0.79 \pm 0.10$ & $5.66 \pm 1.14$ & $8.04 \pm 1.10$ & $0.22 \pm 0.02$ & $2.21 \pm 2.72$ & $3.52 \pm 2.67$ & $3.23 \pm 1.16$ & $0.32 \pm 0.11$ & $7.77 \pm 5.01$ & $7.41 \pm 0.73$ & $8.51 \pm 0.94$ \\
\hline Nov. & $0.22 \pm 0.03$ & $7.17 \pm 4.93$ & $6.39 \pm 1.12$ & $7.63 \pm 1.94$ & $0.30 \pm 0.05$ & $3.80 \pm 3.19$ & $4.32 \pm 0.23$ & $3.79 \pm 1.20$ & $0.45 \pm 0.09$ & $9.75 \pm 4.50$ & $6.75 \pm 1.02$ & $7.78 \pm 1.20$ \\
\hline
\end{tabular}



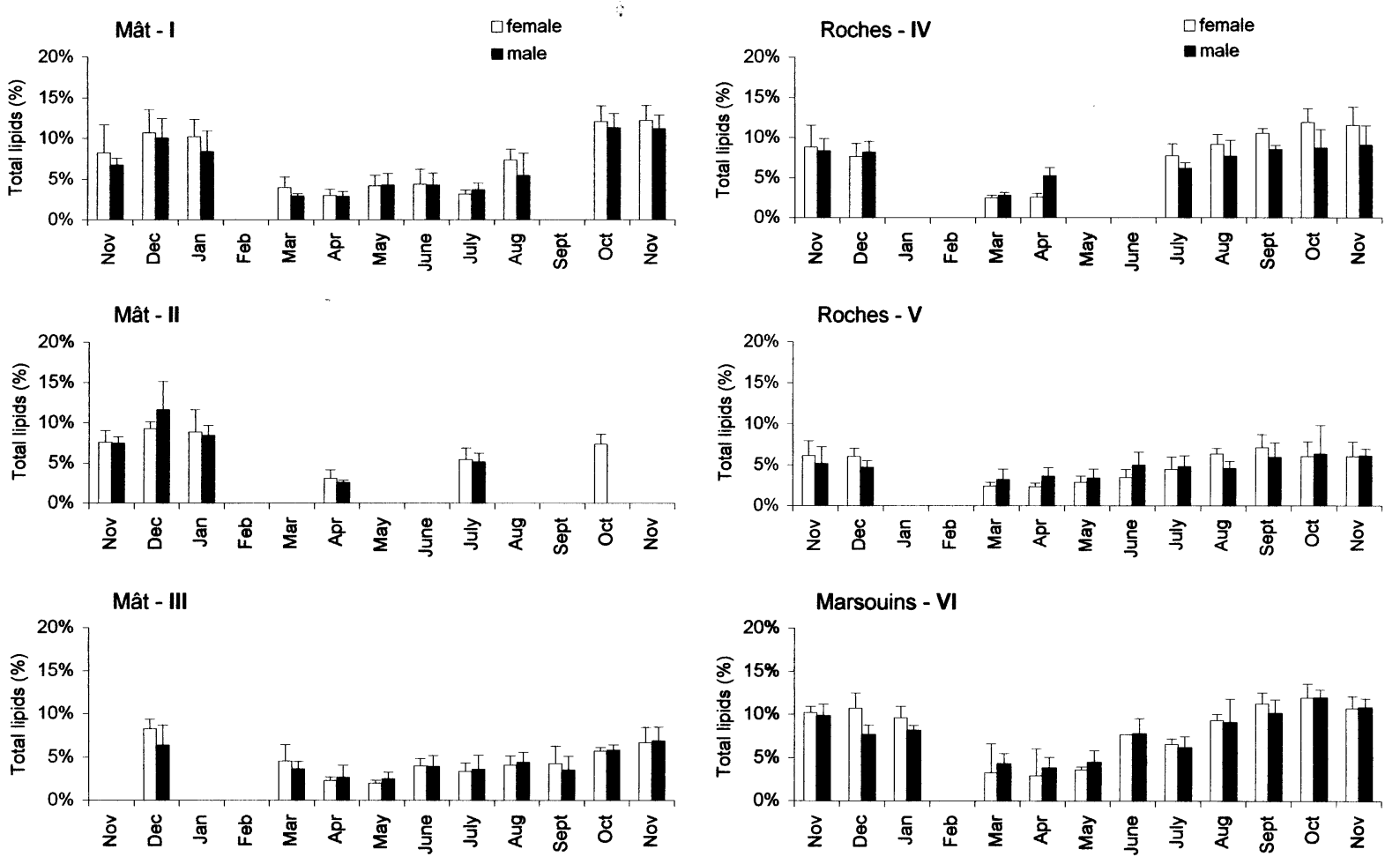

Fig. 6. Seasonal changes in somatic lipid contents (\% dry weight) of male and female S. lagocephalus at sampling sites I - VI.

corded after the high flow events of February 1998 (March - May). Globally, females presented lipid contents slightly stronger than males. Lipid levels were generally lower for animals captured in downstream zones (III, V).

Somatic protein percentage ranged between 53 and $71 \%$ DW (Fig. 7) for both females and males. Variance analysis did not reveal significant differences $(\mathrm{P}>$ $0.05)$ between the two sexes. The highest values were recorded from March to May. They decreased until November before the protein percentage increased again. Variations in protein content were much more marked on downstream stations (II, III, V) compared to sites I and VI.

\section{Discussion}

Periphyton is a complex community of microbiota (algae, fungi, bacteria, animals, organic and inorganic detritus) that are attached to various substrates (Wetzel
1983). Many factors interact for controlling development of algal periphytic communities such as nutrient availability, light, flow velocity, $\mathrm{pH}$, temperature, grazing, which can affect abundance, production and community structure (Fairchild et al. 1985, Steinman \& McIntire 1986, Keithan et al. 1988, Bothwell 1988, 1989, Peterson et al. 1993, Rosemond et al. 1993, Pan \& Lowe 1994, Pringle \& Hamazaki 1997, Rosemond et al. 2000). Several experiments of $N$ and $P$ enrichment suggest that nitrogen availability can constitute an essential element in the regulation of primary benthic production (Lohman et al. 1991, Perrin \& Richardson 1997). In volcanic zones, where phosphates are abundant and nitrogen low, nitrogen represents a significant factor limiting algal growth (Grimm \& Fisher 1986, Peterson \& Grimm 1992). In slightly nitrogenised environments, the minimal threshold range between 55 to $100 \mu \mathrm{g} . \mathrm{l}^{-1}$ of nitrogen is considered as being necessary for benthic algae growth (Grimm \& Fisher 1986, Lohman et al. 1991). In our study, N$\mathrm{NO}_{3}{ }^{-}$concentrations recorded in both Mât and Mar- 

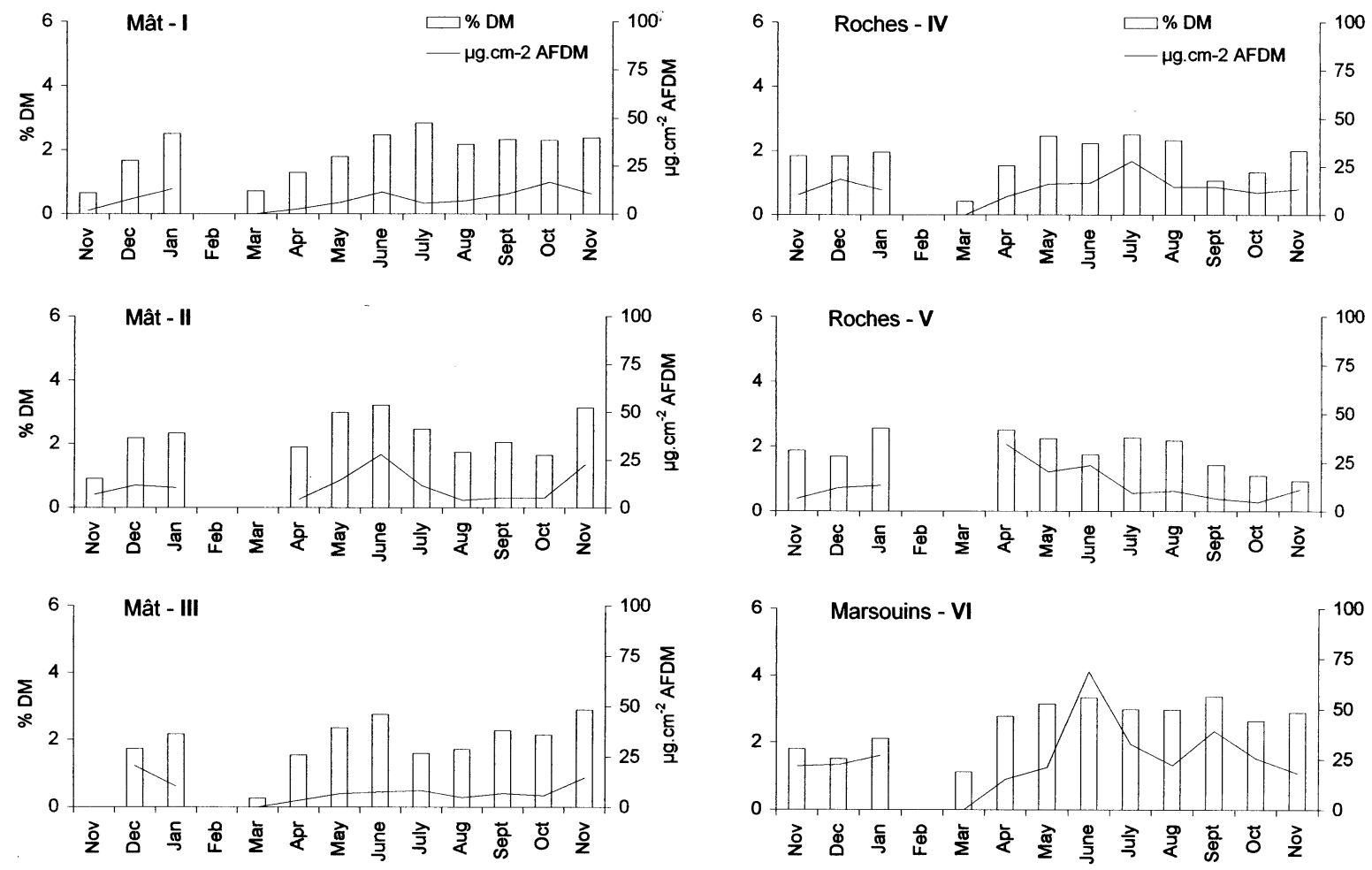

Fig. 7. Seasonal changes in somatic protein contents (\% dry weight)of male and female S. lagocephalus at sampling sites I - VI.

souins streams are much higher and do not seem to be a limiting factor for the algal biomass development. The volcanic character of Réunion Island means that phosphorus contents recorded on the majority of studied sites are largely higher than the concentrations noticed by Bothwell (1989) when benthic algal biomass is maximum (ranged between 25 to $50 \mu \mathrm{g} . \mathrm{l}^{-1}$ of $\mathrm{P}_{-} \mathrm{PO}_{4}{ }^{3-}$ ). In contrast, the Roches stream shows values of $\mathrm{N}_{-} \mathrm{NO}_{3}{ }^{-}$and $\mathrm{P}_{-} \mathrm{PO}_{4}{ }^{3-}$ slightly lower than these thresholds. Finally, high silica concentrations observed for all stations should not limit diatom development. Except for the Roches stream, nutrient concentrations recorded during our study do not seem to be factors limiting the benthic algal development. Nutrient concentrations were the highest in the Mât stream but periphytic biomass was lower than those observed in the Roches where the weakest nutrient concentrations were recorded. In the same way, biomass recorded on site VI (Marsouins) is maximum whereas nutrient contents present intermediate values. These results suggest that nutrient availability is not the only factor determining the periphyton development in this ecosystem. $\mathrm{Nu}$ trient cycling within the biofilm can compensate for deficiency in nutrient concentrations in stream water and thus maintain biomass and periphytic productivity (Mulholland et al. 1995). In New Zealand, a comparable ecosystem, Biggs \& Close (1989) noted that hydrological factors could explain more than $63.3 \%$ of the biomass variance and were as significant as nutrient availability. The exceptional high flows that occurred in Réunion streams (February 1998) are responsible for the strongest reduction in the periphytic biomass. During successive disturbances, Peterson \& Grimm (1992) observed that periphyton became more dependent on nutrient production within the biofilm than of the dissolved element concentrations in water. However, the importance of this autogenic mechanism and the possibility which could make up external supply and thus control algal community remains very variable according to systems and their disturbances.

Protein percentages in algae varied from 19 to $56 \%$ DM (Ahlgren et al. 1992) according to environmental 
conditions (Piorreck et al. 1984, Worm et al. 2000), species (Rathore \& Kumar 1993) or growth phase (Brown et al. 1997). In our study the periphytic algae are mainly constituted by cyanophyta (Bielsa 2000), an algal group which generally have high protein contents. In controlled culture conditions, the protein percentage of cyanophyta is generally higher than $35 \%$ of the dry mass (Ahlgren et al. 1992) and can exceed $50 \%$ when nitrogen availability increases in the medium (Piorreck et al. 1984). Mean annual protein contents recorded on the different study sites range between 10 and $30 \%$ of the dry mass and are lower than those proposed by these authors. This could be explained by the presence of a mineral fraction in samples of the periphyton collected in our study and which, compared to data of algae culture, decreases the protein percentages expressed in $\%$ of the total dry mass. The weak nitrogen concentrations observed in the Roches stream water could explain low protein values recorded in the biofilm. Indeed, a nitrogen deficiency can involve a reduction in protein contents (Ben-Amotz et al. 1985, Aleya 1992).

Algal lipid contents oscillated between 5 and $70 \%$ of the dry mass, more commonly $15-30 \%$ and 8-13\% for species stocking lipids and carbohydrates respectively (Olsen 1998). Ben-Amotz et al. (1985) report that lipid contents of seven marine species vary between 7 and $55 \%$ according to species and culture conditions. Piorreck et al. (1984) indicate, in freshwater cyanophyta, that lipid contents vary from 12 to $18 \%$ of the dry mass. During our study, lipid percentages recorded in the periphyton were weaker. The highest values are lower than $5 \%$ of the dry mass, but are in agreement with those proposed by Ahlgren et al. (1992) for cyanophyta, which mainly constitute the algal periphytic community in our studied streams. Lipid contents of the biofilm sampled in both the Roches and the Mât streams are comparable even if nutrient concentrations, in particular nitrogen, are different. This could be explained by the stability of lipid contents highlighted in cyanophyta maintained under different nitrogen concentrations (Piorreck et al. 1984). However, nutrient availability is not the only factor influencing the algal biochemical composition. Other parameters, such as light (Sicko-Goad \& Andersen 1991, Renaud et al. 1991), temperature (Tedesco \& Duerr 1989) or growth phase (Rathore \& Kumar 1993), act on algal lipid contents. Although not easily quantifiable in our study, they could nevertheless influence both temporal and spatial variability observed in Réunion streams.

The results expressed as a percentage do not reflect protein and lipid bio-availability of the periphyton.
The available quantities per surface unit show differences among stations. The periphyton biomass and the nutritive value were the highest at station VI (Marsouins) and involved a maximum bio-availability of these two parameters. In contrast, protein and lipid percentages were higher on the Mât stream (stations I, II and III) whereas the periphytic biomass was higher on stations IV and V (Roche stream). This involves a more significant availability on these sampled points. These differences were linked more to the periphytic biomass variations than to the intrinsic quality modifications (\% of protein and lipid) at the different stations.

Sicyopterus lagocephalus is a herbivorous benthic fish which is not very selective, with a diet primarily made up of periphytic algae (Bielsa 2000). Many fish have seasonal cycles to build up their energy stock intended for both reproduction and metabolic needs during fasting (Adams 1998). The energy investment reserved for gonad development compared to soma was evaluated at $11 \%$ and $67 \%$ respectively in male and female trout (Jonsson \& Jonsson 1997). This investment is often higher than the energy provided by food (Shul'man 1974). The principal energy source available for the synthesis of reproductive tissues comes from the lipid reserves contained in liver and/or muscle. Mobilisation of the hepatic reserves results in a weight loss of liver (Allen \& Wootton 1982, Lahti \& Muje 1991). After spawning, the liver weight increases faster as the food intake is significant (Bulow et al. 1978, Allen \& Wootton 1982, Tveranger 1985, Crupkin et al. 1988, Singh \& Towheed 1993). In fact, except during reproduction, the hepatosomatic index is considered in fish as a good indicator of both food consumption and energy stock. A decrease of this index indicates insufficient nutritional conditions according to energy needs (Parent et al. 1985, Miglavs \& Jobling 1989, De Silva et al. 1991).

The study of the gonad development cycle in $S$. lagocephalus showed that the reproduction period coincides with summer rains. Gonadal development begins between November and December and the maturation phase extends from February to August. Then a quiescence period of the gonads occurs until October or November. In temperate zones, seasonal fluctuations of temperature and photoperiod are considered to be the principal environmental factors controlling fish reproduction (Gillet 1989, Towsend \& Perrow 1989, Billard \& Breton 1981, Billard 1995). In tropical zones, these parameters vary with low amplitudes, fluctuation of water flow seems to be a dominating factor controlling reproduction. Flow increase induces gonadal recrudes- 
cence and spawning (Kirschbaum 1979, 1992, Albaret 1982, Legendre \& Jalabert 1988, Mutambue \& Tourenq 1996). Delacroix $(1987,1992)$ noted, for Sicyopterus lagocephalus, that the gonadosomatic index increased with high flow and was followed by massive spawning. This relation between flow variations and gonad maturation and/or spawning did not clearly appear during our study, suggesting that the hydrology will not be the only factor controlling reproduction.

The hepatosomatic index of Sicyopterus lagocephalus decreased during both the final phase of the gonadal development and the first spawning period (January 1998). Fish with an equivalent degree of maturity (similar GSI) and captured after the significant rainfall peak of February 1998 have a HSI two to three times weaker, a consequence of a strong mobilisation of the energy reserves in these fish. During high flow, the degradation of nutritional conditions did not counterbalance the energy losses linked to reproduction and/or swimming activity. Unlike the observations carried out by Kirschbaum (1992) on various tropical species, the stress conditions related to food limitation induced by high water level do not seem to modify reproduction activities for $S$. lagocephalus. Hepatosomatic index recovers comparable values with those obtained before rising after breeding (June or July). The reconstitution of energy reserves continues even when fish start a new reproductive cycle. It appeared that there was a relationship between food availability and hepatosomatic index. Thus, stations where the food availability was the lowest (V, II, III) were less favourable to stock reserves in liver compared to the richest stations (VI) where HSI was particularly high.

In fish, substantial quantities of lipids are reserved for gonadal development (Wootton 1977, Love 1980, Henderson \& Tocher 1987, Tanasichuk \& Mackay 1989, Adams 1998). Storage level in females and the efficiency of its allocation for gonad maturation will be determining for reproductive success (Watanabe 1985, Rainuzzo et al. 1997, Adams 1998). Many works highlight a strong increase in body fats after spawning corresponding to the reconstitution of energy reserves, especially in the form of lipids (Nikolsky 1963, Craig 1977, Penczak et al. 1978, Allen \& Wootton 1982, Parent et al. 1991). Lipid levels are directly related to the food ingested (quantity and/or quality) and constitute a good index for estimating fish conditions (Elliott 1976, Penczak et al. 1977, 1978, Dos Santos et al. 1993). Results of the biochemical analyses carried out on S. lagocephalus showed that fish used their lipids during gonad maturation. However, the reproductive cycle is not the main factor respon- sible for seasonal variations of the reserves. After changes in water level which occurred in February 1998, the somatic lipid levels in fish with an equivalent gonadosomatic index were two to three times lower than those observed before high flow conditions. During months of high water level, the swimming activity and the decrease of both quantity and quality of food availability largely contributed to the reduction of energy storage. In spite of a high nutritional activity, fish maintain low somatic lipid levels suggesting that reproductive activity consumes more energy than what is provided by food. The reconstitution of lipid reserves begins between the June-July period, characterised by the most favourable nutritional conditions. The somatic lipid increase was less significant where food quantity and quality were the weakest (stations: V, II, III). In contrast, despite less favourable nutritional conditions on station IV compared to VI, the energy reserves reconstitution was similar for the two sites. No change in protein content was noted after the high flow period, suggesting that no mobilisation occurred. Lipid reserves would be sufficient to compensate the energy needs induced by reproduction and hydrological disturbances.

The rainfall succession has definitely affected the periphytic availability for Sicyopterus lagocephalus. In tropical lotic environments, hydrological variations have a significant influence on the benthic algal communities. The fish grazing impact would seem also to play a major role in both the algal population structure and biomass fluctuations (Pringle \& Hamazaki 1997). The hydrological conditions constitute the main factor controlling the physiological conditions of S. lagocephalus. Nevertheless, despite unfavourable nutritional conditions (weak quantitative availability) they maintain reproductive activity. However, reduction in reproductive success during high flow events could explain inter-annual variations of recruitment. The knowledge of these phenomena could be useful for an effective halieutic management of this resource for preserving this species which is of social and economic local interest.

\footnotetext{
Acknowledgements

The authors wish to thank «Le Conseil Régional de la Réunion» and «Le Laboratoire Régional des Fraudes (D.G.C.C.R.F.)» for their financial and technical support. We thank Pr. R. Le Cohu, E. Chabanne, N. Ferroni and J. Brabet for their field and laboratory assistance during this study.

\section{References}

Aboussouan A. 1969. — Note sur les «bichiques» de l'île de La Réunion. Rec. Trav. Sta. Mar. Endoume. Fasc. hors série suppl. ${ }^{\circ} 9$ : 25-31.
} 
Adams S.M. 1998. — Ecological role of lipids in the health and success of fish populations. Pages 132-160 in Arts M.T. \& Wainman B.C. (eds). Lipids in freshwater ecosystems. Springer-Verlag New York.

Ahlgren G., Gustafsson I.B. \& Boberg M. 1992. — Fatty acid content and chemical composition of freshwater microalgae. $J$. Phycol., 28, 37-50.

Albaret J.J. 1982. — Reproduction et fécondité des poissons d'eau douce de Côte d'Ivoire. Rev. Hydrobiol. Trop., 15, 347-371.

Aleya L. 1992. - The seasonal succession of phytoplankton in an eutrophic lake through the coupling of biochemical composition of particulates, metabolic parameters and environmental conditions. Arch. Hydrobiol., 124, 69-88.

Allen J.R.M. \& Wootton R.J. 1982. — Effect of food on the growth of carcass, liver and ovary in the female Gasterosteus aculeatus L. J. Fish Biol., 21, 537-547.

A.R.D.A, 1996. - Inventaire des cours d'eau pérennes de la Réunion. Technical Report, ARDA-DIREN Réunion.

Ben-Amotz A., Tornabene T.G. \& Thomas W.H. 1985. - Chemical profile of selected species of microalgae with emphasis on lipids. J. Phycol., 21, 72-81.

Bertrand J. 1985. — La pêche maritime à la Réunion : trente années d'effort et de développement de la production. L'Economie de la Réunion. INSEE, 15, 3-8.

Bielsa S. 2000. - Composition biochimique du périphyton et de $\mathrm{Si}$ cyopterus lagocephalus (Gobiidae, Sicydiinae) dans différentes rivières de l'Ile de la Réunion - Relations trophiques. $\mathrm{PhD}$ dissertation. Univ. Paul Sabatier, Toulouse, 203 p.

Biggs B.J.F. \& Close M.E. 1989. — Periphyton biomass dynamics in gravel bed rivers : the relative effects of flows and nutrients. Freshwat. Biol., 22, 209-231.

Billard R. 1995. — Les carpes - biologie et élevage. Hydrobiologie et Aquaculture, INRA ed. pp 83-100.

Billard R. \& Breton B. 1981. — Le cycle reproducteur chez les poissons téléostéens. Cah. Lab. Hydrobiol. Montereau, 12, 43-56.

Bligh E.G. \& Dyer W.J. 1959. - A rapid method of total lipid extraction and purification. Can. J. Biochem. Physiol., 37, 911-917.

Bothwell M.L. 1988. — Growth rate responses of lotic periphytic diatoms to experimental phosphorus enrichment: the influence of temperature and light. Can. J. Fish. Aquat. Sci., 45, 261-270.

Bothwell M.L. 1989. — Phosphorus-limited growth dynamics of lotic periphytic diatom communities: areal biomass and cellular growth rate responses. Can. J. Fish. Aquat. Sci., 46, 1293-1301.

Bourrely P. \& Couté A. 1986. — Algues d'eau douce de l'Ile de la Réunion. Cryptogam., Algol., 7, 87-121.

Brown M.R., Jeffrey S.W., Volkman J.K. \& Dunstan G.A. 1997. Nutritional properties of microalgae for mariculture. Aquaculture, 151, 315-331.

Bulow F.J., Coburn C.B. \& Cobb J.R. 1978. - Comparisons of two bluegill populations by means of the RNA-DNA ratio and liver somatic index. Trans. Am. Fish. Soc., 107, 799-803.

Champeau, A. 1982. - Aménagement de Takamaka II (amont) sur la Rivière des Marsouins et son affluent le Bras Cabot - Etude d'impact. E.D.F. centre de la Réunion.

Crisman T.L. \& Streever W.J. 1996. - The legacy and future of tropical limnology. Pages 27-42 in Schiemer F. \& Boland K.T. (eds). Perspectives in Tropical Limnology. SPB Academic Publishing, Amsterdam, The Netherlands.

Crupkin M., Montecchia C.L. \& Trucco R.E. 1988. - Seasonal variations in gonadosomatic index, liver-somatis index and myosin/actin ratio in actomyosin of mature hake (Merluccius hubbsi). Comp. Biochem. Physiol., 89 A (1), 7-10.
De Silva S.S., Gunasekera R.M. \& Shim K.F. 1991. — Interactions of varying dietary protein and lipid levels in youg red tilapia: evidence of protein sparing. Aquaculture, 95, 305-318.

Delacroix P. 1987. — Etude des «bichiques», juvéniles de Sicyopterus lagocephalus (Pallas), poisson Gobiidae migrateur des rivières de La Réunion (Océan Indien) : exploitation, répartition, biologie de la reproduction et de la croissance. $\mathrm{PhD}$ dissertation. Univ. Réunion, 144 p.

Delacroix P. 1992. — Irrigation du littoral ouest Transfert Salazie : Etude complémentaire de la biologie, de la répartition et des niveaux de capture des populations de bichiques de la Rivière du Mât. D.A.F., 66 p.

Dos Santos J., Burkow I.C. \& Jobling M. 1993. — Patterns of growth and lipid deposition in cod (Gadus morhua L.) fed natural prey and fish-based feeds. Aquaculture, 110, 173-189.

Elliott J.M. 1976. - Body composition of brown trout (Salmo trutta L.) in relation to temperature and ration size. J. Anim. Ecol., 45 , 273-289.

Fairchild G.W., Lowe R.L. \& Richardson W.B. 1985. - Algal periphyton growth on nutrient-diffusing substrates: an in situ bioassay. Ecology, 66, 465-472.

Gillet C. 1989. — Le déroulement de la fraie des principaux poissons lacustres. Hydroécol. Appl., 1/2, 117-143.

Craig J.F. 1977. - The body composition of adult perch, Perca fluviatilis in Windermere, with reference to seasonalchanges and reproduction. Anim. Ecol., 46, 617-632.

Grimm N.B. \& Fisher S.G. 1986. - Nitrogen limitation in a Sonoran Desert stream. J. N. Am. Benthol. Soc., 5, 2-15.

Henderson R.J. \& Tocher D.R. 1987. — The lipid composition and biochemistry of freshwater fish. Prog. Lipid Res., 26, 281-347.

Jonsson N., Jonsson B. \& Hansen L.P. 1997. — Changes in proximate composition and estimates of energetic costs during upstream migration and spawning in Atlantic salmon Salmo salar. J. Anim. Ecol., 66, 425-436.

Keithan E.D., Lowe R.L. \& DeYoe H.R. 1988. - Benthic diatom distribution in a Pennsylvania stream: role of $\mathrm{pH}$ and nutrients. $J$. Phycol., 24, 581-585.

Kirschbaum F. 1979. - Reproduction of the Weakly Electric Fish Eigenmannia virescens (Rhamphichtyidae, Teleostei) in captivity. I - Control of gonadal recrudescence and regression by environmental factors. Behav. Ecol. Sociobiol., 4, 331-355.

Kirschbaum F. 1992. - Environmentally controlled periodical reproduction of tropical freshwater fish. Proceedings of the international australian lungfish breeding workshop, Cleveland, Ohio : 51-103.

Lahti E. \& Muje P. 1991. — Egg quality and female condition in vendace (Coregonus albula L.) before and during spawning. Hydrobiologia, 209, 175-182.

Legendre M. \& Jalabert R. 1988. - Physiologie de la reproduction. In Biologie et Ecologie des Poissons d'Eau Douce Africains, pp. 153-175, Trav. Doc. Inst. Fr. Rech. Sci. Dév. Coop. ORSTOM., no. 216.

Lohman K., Jones J.R. \& Baysinger-Daniel C. 1991. — Experimental evidence for nitrogen limitation in a northern Ozark stream. $J$. N. Am. Benthol. Soc., 10, 14-23.

Lorenzen C.J. 1967. — Determination of chlorophyll and pheopigments: spectrophotometric equations. Limnol. Oceanogr., 1, 343-346.

Love R.M. 1980. - The Chemical biology of fishes, 2. Academic Press, London and New York, 943 p.

Marker A.H.F., Nush E.A. \& Rieman B. 1980. — The measurement of photosynthetic pigments in freshwaters and standardization of method: conclusions and recommendations. Ergeb. Limnol., 14, 91-106. 
Miglavs I. \& Jobling M. 1989. - The effects of feeding regime on proximate body composition and patterns of energy deposition in juvenle arctic charr (Salvelinus alpinus). J. Fish. Biol., 35, 1-11.

Mulholland P.J., Marzolf E.R., Hendricks S.P., Wilkerson R.V. \& Baybayan A.K. 1995. — Longitudinal patterns of nutrient cycling and periphyton characteristics in streams: a test of upstreamdowstream linkage. J. N. Am. Benthol. Soc., 14, 357-370.

Mutambue S. \& Tourenq J.N. 1996. — Premières observations sur la structure ovarienne et la fécondité de Barbus holotoenia Boulenger, 1902 (Pisces : Cyprinidae) récoltés dans le bassin de la rivière Luki (Zaire). Ann Limnol., 32, 251-258.

Nikolsky G.V. 1963. - The ecology of fishes. Academic Press. London and New York, $352 \mathrm{p}$.

Olsen Y. 1998. - Lipids and essential fatty acids in aquatic food webs: what can freshwater ecologists learn from mariculture ? Pages 161-202 in Arts M.T. \& Wainman B.C. (eds). Lipids in freshwater ecosystems. Springer-Verlag New York.

O.R.E. 1999. - Annuaire Hydrologique 1999. CD-rom.

Pan Y. \& Lowe R.L. 1994. - Independent and interactive effects of nutrients and grazers on benthic algal community structure. $\mathrm{Hy}$ drobiologia, 291, 201-209.

Parent J.P., Caminade V. \& Vellas F. 1985. — Evaluation de l'état nutritionnel du gardon (Rutilus rutilus) et de la perche (Perca fluviatilis) capturés dans la retenue de Pareloup. Etude préliminaire. Ichtyophysiologica Acta, 9, 202-219.

Parent J.P., Ferroni J.M., Bau F. \& Vellas F. 1991. — Variations quantitatives des protéines, lipides et cendres somatiques chez le gardon capturé, à différentes saisons dans une retenue mésotrophe. Fish Nut. Pract., 61, 307-312.

Penczak T., Molinsky M., Kusto E., Ichniowka B. \& Zalewski, M. 1977. - The ecology of roach, Rutilus rutilus (L.), in the barbel region of the polluted Pilica River. III. Lipids, protein, total nitrogen and caloricity. Ekol. Pol., 25, 75-88.

Penczak T., Molinsky M. \& Oska M. 1978. - Materials for the ecology of the dace (Leuciscus leuciscus L.) from a polluted river in the region of barbel (the River Pilica). 3 . Lipids, protein, total nitrogen and caloric value. Acta Hydrobiol., 20, 97-108.

Perrin C.J. \& Richardson J.S. 1997. - N and P limitation of benthos abundance in the Nechako River, British Columbia. Can. J. Fish. Aquat. Sci., 54, 2574-2583.

Peterson C.G. \& Grimm N.B. 1992. - Temporal variation in enrichment effects during periphyton succession in a nitrogen-limited desert stream ecosystem. J. N. Am. Benthol. Soc., 11, 20-36.

Peterson C.G., Dudley T.L., Hoagland K.D. \& Johnson L.M. 1993. - Infection, growth, and community-level consequences of a diatom pathogen in a Sonoran Desert stream. J. Phycol., 29, 442-452.

Piorreck M., Baasch K.-H. \& Pohl P. 1984. — Biomass production, total protein, chlorophylls, lipids and fatty acids of freshwater green and blue-green algae under different nitrogen regimes. Phytochemistry, 23, 207-216.

Pringle C.M. \& Hamazaki T. 1997. — Effects of fishes on algal response to storms in a tropical stream. Ecology, 78, 2432-2442.

Rainuzzo J.R., Reitan K.I. \& Olsen Y. 1997. — The significance of lipids at early stages of marine fish: a review. Aquaculture, 155, 103-115.

Rathore D.S. \& Kumar A. 1993. — Protein, lipid, and carbohydrate content of three microalgae. Phykos, 32, 9-12.

Reitan K.I., Rainuzzo J.R. \& Olsen Y. 1994. — Effect of nutrient limitation on fatty acid and lipid content of marine micralgae. $J$. Phycol., 30, 972-979.
Renaud S.M., Parry D.L., Thinh L.V., Kuo C., Padovan A. \& Sammy N. 1991. - Effect of light intensity on the proximate biochemical and fatty acid composition of Isochrysis sp. and Nannochloropsis oculata for use in tropical aquaculture. J. Applied Phycology, 3, 43-53.

Rosemond A.D., Mulholland P.J. \& Elwood W. 1993. — Top-down and bottom-up of stream periphyton: effects of nutrients and herbivores. Ecology, 1264-1280.

Rosemond A.D., Mulholland P.J. \& Brawley S.H. 2000. — Seasonally shifting limitation of stream periphyton: response of algal populations and assemblage biomass and productivity to variation in light, nutrients, and herbivores. Can. J. Fish. Aquat. Sci., 57, 66-75.

Shul'man G.E. 1974. — Life cycles of fish. Physiology and biochemistry. J. Wiley and sons, New York, Toronto, Israël, Program for scientific translations., $258 \mathrm{p}$.

Sicko-Goad L. \& Andresen N.A. 1991. — Effect of growth and light/dark cycles on diatom lipid content and composition. J. Phycol., 27, 710-718.

Singh B.N. \& Towheed M.A. 1993. - Water and lipid profiles in the fresh water swamp eel, female Monopterus cuchia (Ham) in relation to annual reproductive and environmental conditions. J. Freshwat. Biol., 5, 183-190.

Steinman A.D. \& McIntire C.D. 1986. — Effects of current velocity and light energy on the structure of periphyton assemblages in laboratory streams. J. Phycol., 22, 352-361.

Tanasichuk R.W. \& Makay W.C. 1989. — Quantitative and qualitative characteristics of somatic and gonadal growth of yellow perch, Perca flavescens, from lac Ste Anne, Alberta. Can. J. Fish. Aquat. Sci., 46, 989-994.

Tedesco M.A. \& Duerr E.O. 1989. — Light, temperature and nitrogen starvation effects on the total lipid and fatty acid content and composition of Spirulina platensis UTEX 1928. J. Applied Phycology, 1, 201-209.

Towsend C.R. \& Perrow M.R. 1989. — Eutrophication may produce population cycles in roach, Rutilus rutilus (L.), by two contrasting mechanisms. J. Fish Biol., 34, 161-164.

Tveranger B. 1985. - Variation in growth rate, liver weight and body composition at first sexual maturity in rainbow trout. Aquaculture, 49, 89-99.

Watanabe T. 1985. - Importance of the study of broodstock nutrition for further developement of aquaculture. Pages 395-414 in Cowey C.B., Mackie A.M. \& Bell J.G. (eds). Nutrition and Feeding in Fish. Academic Press, London.

Wetzel R.G. 1983. - Recommandations for future research on periphyton. Periphyton of freshwater ecosystem. Wetzel, R.G. eds, The Hague, Dr. W. Junk Publishers.

Wilkinson L. 1989. - Systat: the system for statistics. Evanston, Illinois : systat INC, 638 pp.

Wootton R.J. 1977. - Effect of food limitation during the breeding season on the size, body components and egg production of female sticklebacks (Gasterosteus aculeatus). J. Anim. Ecol., 46, 823-834.

Worm B., Lotze H.K. \& Sommer U. 2000. - Coastal food web structure, carbon storage, and notrogen retention regulated by consumer pressure and nutrient loading. Limnol. Oceanogr., 45, 339-349. 